\title{
Reflecting on the Growth of Indigenous Self-employment
}

\author{
Boyd Hunter ${ }^{1}$
}

\begin{abstract}
Indigenous self-employment has increased substantially in the last two decades. Government organisations and programs that finance and support the success of Indigenous business provide one explanation for this trend. However, private-sector initiatives also have a role to play. Self-employment is a heterogeneous statistical category that conflates employers with other self-employed who do not employ other workers. Furthermore, it does not take into account the legal status of the business that the owner-manager operates within. Nevertheless, the recent growth in selfemployment means that there are enough Indigenous ownermanagers in Australia that future analysis can meaningfully disaggregate census data to gain greater insights into Indigenous business.
\end{abstract}

\section{Introduction}

Historically, Indigenous people have largely been excluded from building businesses in Australia. For example, in the 1860s a group of Aborigines lead by Simon Wonga 'squatted' on a property near Melbourne they called 'Coranderrk', which was developed as a farm that generated considerable revenue (Pascoe 2008). While the local community initially gained some autonomy in the operation of the enterprise, financial control remained with the Aboriginal Protection Board. The appropriation of profits meant that there was no monetary incentive to develop the business; and hence after initial promise, the venture lapsed. Instead of the independent community enterprise envisaged by these Aboriginal proto-entrepreneurs, dependency on the state was perpetrated by bureaucratic control over their day-to-day lives.

Protection Boards, and related authorities, were dismantled in the mid20th century, but they have left several legacies that ensure that Indigenous disadvantage has considerable inertia. The historical restrictions on Indigenous freedoms have limited the possibility for potential entrepreneurs to acquire an

1 Australian National University, Boyd.Hunter@anu.edu.au. 
adequate education or secure employment. Having been dispossessed of land, and limited in the opportunity for capital accumulation and acquisition of labour market skills, it is not surprising that until recently relatively few Indigenous people have attempted to run their own businesses.

The research on Indigenous business is limited by the fact that we do not have universally accepted definitions of what constitutes an Indigenous business (Foley and Hunter 2013). If Indigenous people hold more than half the equity in a business then there is likely to be substantial Indigenous control in the operation of the business. Foley (2005) argues that majority equity criteria should be relaxed to include situations where only half the equity is held by Indigenous people, while the Forrest (2014) Report argues that this threshold could be reduced to at least 25 per cent Indigenous equity (in conjunction with other criteria; see recommendation 18).

Even if the concept of an Indigenous business was easy to define and measure, the debate would be held back by the lack of information on potential Indigenous businesses. This paper seeks to further the debate by documenting recent trends in Indigenous self-employment, especially those who employ other people. Obviously self-employment is conceptually different to a business, as it refers to an individual rather than a social organisation, but the self-employed have to bear the risk of their own economic activities and hence are entrepreneurial by definition (Cantilion 1730).

Using self-employment data from 2011 and earlier censuses, this paper documents the extent to which the historical exclusion of Indigenous entrepreneurs has changed, with a particular focus on the changing numbers of Indigenous employers. The central thesis of this paper is that Indigenous self-employed are a diverse group and that this diversity needs to understood and analysed. The recent growth in Indigenous self-employment means that there are now enough Indigenous owner-managers in Australia that future analysis can meaningfully disaggregate census data to gain greater insights into the various types of Indigenous businesses.

\section{Policy and relevant context}

Indigenous-specific government policies and programs may play an important role in recent trends in Indigenous self-employment. At the Commonwealth level, the Indigenous Employment Program (IEP) has committed some \$991 million over the five years to 2014/15 (DEEWR 2011). Some of the key components of the IEP are Indigenous Wage Subsidy, which may assist Indigenous entrepreneurs who employ other Indigenous people. Two relevant components of the IEP in the context of this paper are the Indigenous Small Business Fund and the 
Indigenous Capital Assistance Scheme that offer Indigenous businesses access to commercial finance, and appropriate professional and mentoring support services. Other aspects of the IEP that support Indigenous business include: provide information on how to start a business; obtain financial literacy training; conduct feasibility studies; develop and implement business plans and risk-management plans; support the development and implementation of community or regional development plans and other strategic initiatives (Gray, Hunter and Lohoar 2012).

The Australian Government's Indigenous Opportunities Policy (IOP) requires government officials responsible for projects involving expenditure of over \$5 million (\$6 million for construction) to ensure tenders include a plan for providing training and employment opportunities to local Indigenous communities and for the use of Indigenous suppliers that are small and medium enterprises (DEEWR 2013).

The private sector also has a direct role to play in supporting Indigenous business. One interesting development is the establishment of various Indigenous Chambers of Commerce in various states and in Canberra. The Indigenous Business Council of Australia is the peak body for these organisations, which provides a voice of Indigenous business owners from all sectors of the economy.

The mining sector has a particular interest in developing good relations with local Indigenous communities, especially where Native Title determinations have established the right to negotiate. Mining companies have policies that facilitate community relations and to otherwise influence public relations. For example, Fortescue Metals Group (FMG) has recently committed itself to $\$ 1$ billion in contracts to Aboriginal businesses by June 2013 (see www.fmgl.com.au accessed online 26 September 2014). Rio Tinto has also made enormous commitment of a minimum 13.9 per cent of Pilbara expenditure to local Aboriginal businesses. Note that the contracted Indigenous businesses may not necessarily be directly in mining, even though they probably involve the servicing of mining and related local communities. These are enormous private-sector commitments to Indigenous business which, if realised, will have important implications for the size and operation of the Indigenous self-employment sector. I will return to such issues in the concluding sections.

The Australian Indigenous Minority Supplier Council (AIMSC), or as it is now known 'Supply Nation', was established in 2009 to foster the Indigenous enterprise sector by integrating Indigenous small-to-medium enterprises into the supply chains of Australian companies and government agencies. It aims to achieve this by advocating on behalf of the Indigenous business community to foster business-to-business transactions and commercial partnerships between corporate Australia, government agencies and Indigenous business; 
and exchanging information, conducting research and leading the integration of Indigenous business into the Australian economy. Currently, the Supply Nation website indicates that it has 154 members from corporate Australia, not-for-profit companies and Australian government agencies, all of which are committed to doing business with Supply Nation certified suppliers. Note that at last count there are 287 Indigenous businesses certified by Supply Nation as being ready to 'do business' (up from 169 certified businesses in 2013). Since 2009, Supply Nation has claimed to achieve \$108 million-worth of transactions between its members and certified suppliers, with $\$ 105$ million-worth of contracts awarded to its certified suppliers (see www.supplynation.org.au, accessed 26 September 2014).

\section{Recent trends in Indigenous and other self- employment}

In order to understand the recent growth in Indigenous self-employment we need to identify comparable data. Previous analysis of trends has been constrained by substantial changes in the way official statistical collections ask about selfemployment. However, recent census data is more inter-temporally consistent and hence it is worth revisiting the trends in Indigenous self-employment.

Between 1991 and 1996 there was a substantial decrease in the proportion of employed persons in 'employer' and 'own-account worker' categories for both Indigenous and other Australians, which appeared to be associated with a change in the way the question was asked (see Hunter 2013). In 1996 the Census question asked whether the business was in a 'limited liability' company rather than the historical question about 'own business employing others'. The prevalence of self-employment in 2001 was more consistent with historical expectations when the question was changed back to that used in the 1991 Census. For 2006 and 2011, type of employment is split into two questions in order to produce data which are more closely aligned with standard labour-force concepts collected in the ABSs Labour Force Survey.

With the exception of the 1996 data, census information was collected in a broadly comparable fashion in the last five censuses. This data series shows a steady improvement in Indigenous self-employment since the early 1990s, although this improvement has been occurring from a low base (see Figure 1). The trend for non-Indigenous self-employment is less clear, as it increased to 2006 but fell in the last inter-census period. Overall non-Indigenous selfemployment increased by less than Indigenous self-employment in the 20 years to 2011 , with the net result being a reduction in the gap in Indigenous and non- 
Indigenous outcomes in both relative and absolute terms. Notwithstanding this, the prevalence of self-employment in the Indigenous population is still around one-third that for other Australians.

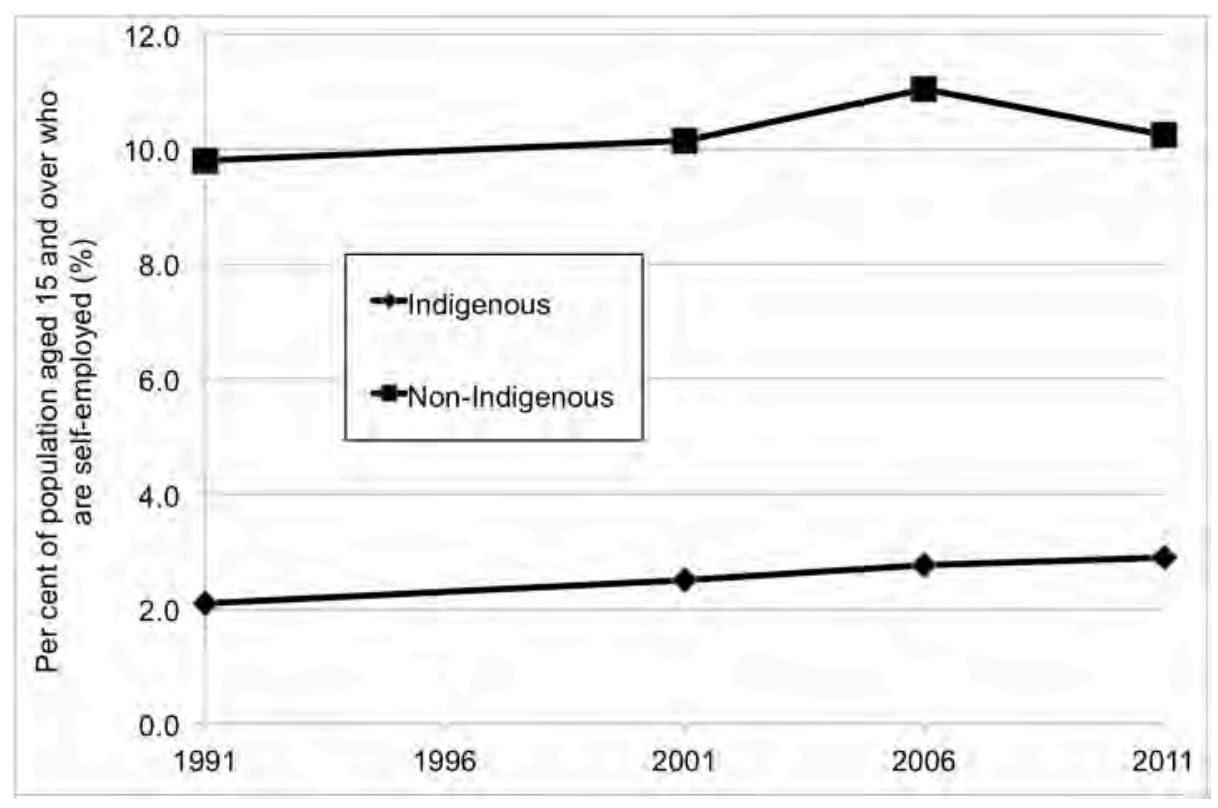

Figure 1: Trends in self-employment by Indigenous status, 1991-2011

Sources: Self-employment numbers are drawn from Daly (1995), Hunter (2004) and ABS Table Builder for the last two censuses. The 1991 census estimates also use other labour force information from Altman, Biddle and Hunter (2009) to rescale the rates expressed as a proportion of the labour force. The 1996 estimates are omitted because the question was changed so that it was not comparable with 1991, but the 2001 Census question reverted to a more comparable form (see Hunter 2013, Appendix A).

The growth in the Indigenous population was much greater than that indicated by adding the number of births of Indigenous children and subtracting deaths within the population. Some potential reasons for this non-biological growth in the population include improved census enumeration of the Indigenous population, a decrease in the number of people for whom this question was not answered, and people changing their ethnic identification in the census over time (Biddle 2012). Theoretically, this non-biological growth can effect changes in composition of the Indigenous population; however, in practice the effects are very small in the short run. Hunter (1998) demonstrates the compositional effects are not significant for Indigenous Australians when comparing populations over a decade. 
The increase in the numbers of Indigenous self-employed is even larger when one takes into account both population growth and the propensity to undercount Indigenous Australians in census data using the estimated residential populations (ERPs) for people aged 15 and over (see Figure 2). The number of Indigenous self-employed increased by a factor of 2.7, from 4,600 to 12,500, between 1991 and 2011. While this was largely driven by population growth, it may also provide some evidence of an emerging Indigenous middle class (Lahn 2012). Over the same period the number of non-Indigenous selfemployed increased by a factor of 2.6 , from 0.7 million to 1.8 million. Part of the reason for the slightly higher increase in the Indigenous self-employment vis-àvis that for other Australians is the recent increase in the propensity to identify as Indigenous in official statistical collections (Biddle 2012). Nevertheless, it is noteworthy that, in contrast to the non-Indigenous statistics in Figure 1, the prevalence of Indigenous self-employment increased substantially in each of the last three censuses.

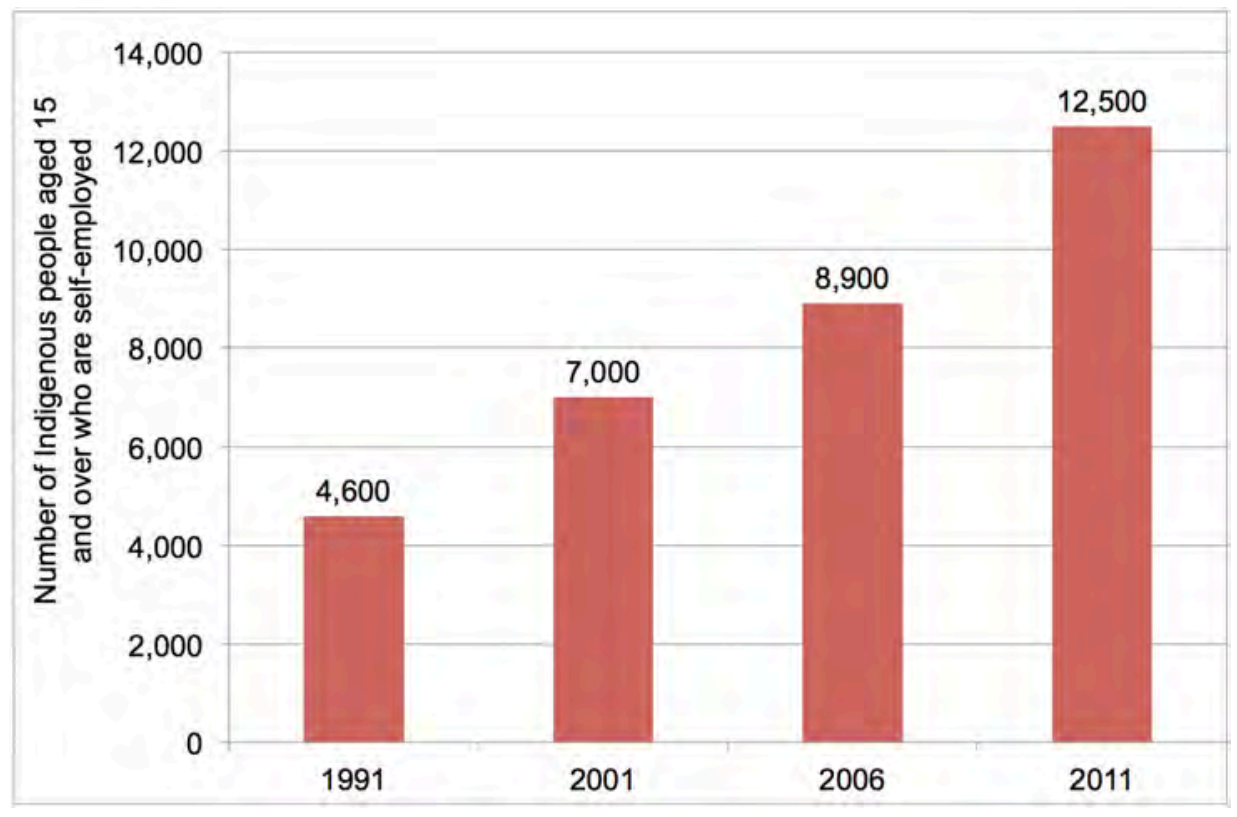

\section{Figure 2: Estimated number of Indigenous self-employed, 1991-2011}

Source: The estimates in Figure 2 are based on census counts which are adjusted to take into account Indigenous under-enumeration using the ERPs. Before 2011, ERPs are estimated to be consistent with the adjusted 2006 Indigenous population aged 15 and over (see ABS 2009; 2012).

Figures 3 and 4 seek to further unpack these trends by identifying what happened to Indigenous and non-Indigenous employers and other self-employed in the last 
two censuses for remote and non-remote areas. The reason for focusing on the last two censuses is that both the census questions and geographic definitions used are directly comparable for that period.

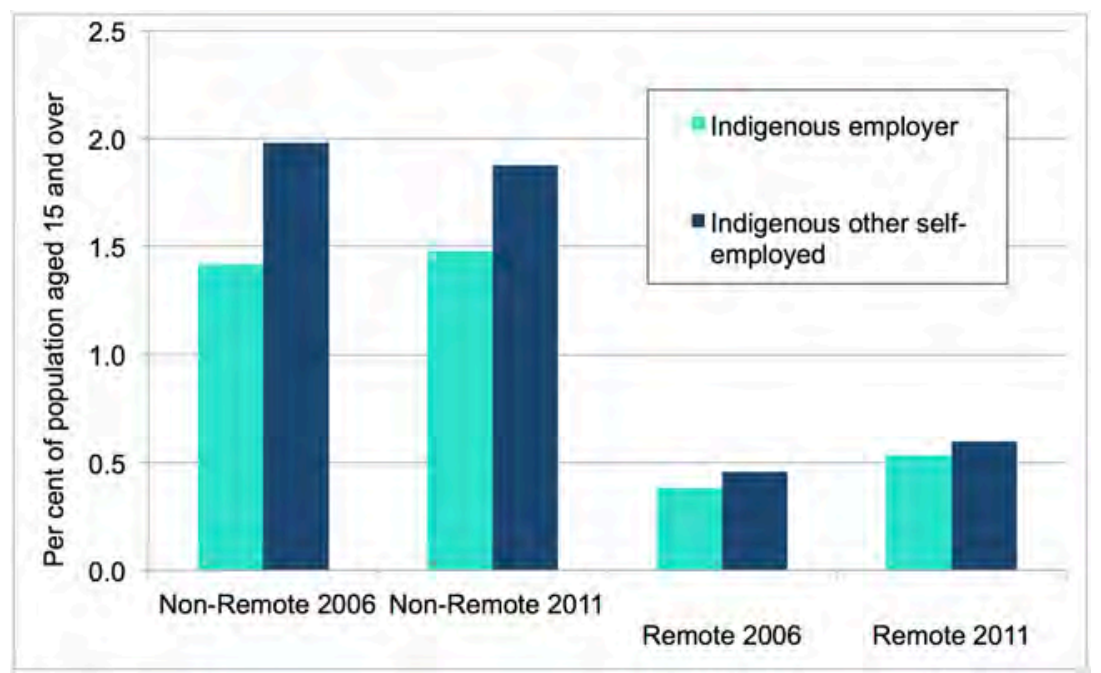

\section{Figure 3: Recent trends in Indigenous employer status and remoteness}

Notes: Broad remoteness classification is based on the geographic boundaries used for the 2006 census. Remote and non-remote statistics are calculated using geographic concordances provided by the ABS for Statistical Area level 1. Other self-employed are owner/managers of either incorporated or unincorporated bodies without any employees.

Source: ABS Table Builder.

The first thing to note in Figure 3 is that the increase in the total Indigenous self-employment rate is driven by a small increase in employers in non-remote areas and a slightly larger increase in both employer and other self-employed in remote areas. Other self-employed actually decreased slightly in non-remote areas.

Notwithstanding the relative emphasis in the current public debate on Indigenous contractors in the mining sector, which is often physically located in remote areas, Indigenous self-employed in non-remote areas are still the largest group of Indigenous self-employed. While Indigenous contractors for the mining sector may be fly-in-fly-out (Fifo) workers - like a substantial proportion of the current mining workforce - the relative prominence of non-remote residences among Indigenous self-employed pre-dates the current mining boom (Hunter 2004; Foley 2006).

Figure 4 presents the same information for the non-Indigenous population (presented on a different scale to that used in Figure 3). In contrast to the 
Indigenous population, the prevalence of non-Indigenous self-employment is higher in remote areas rather than non-remote areas; however, the prevalence of employers and other self-employed declined among the non-Indigenous population in both remote and non-remote areas between 2006 and 2011 .

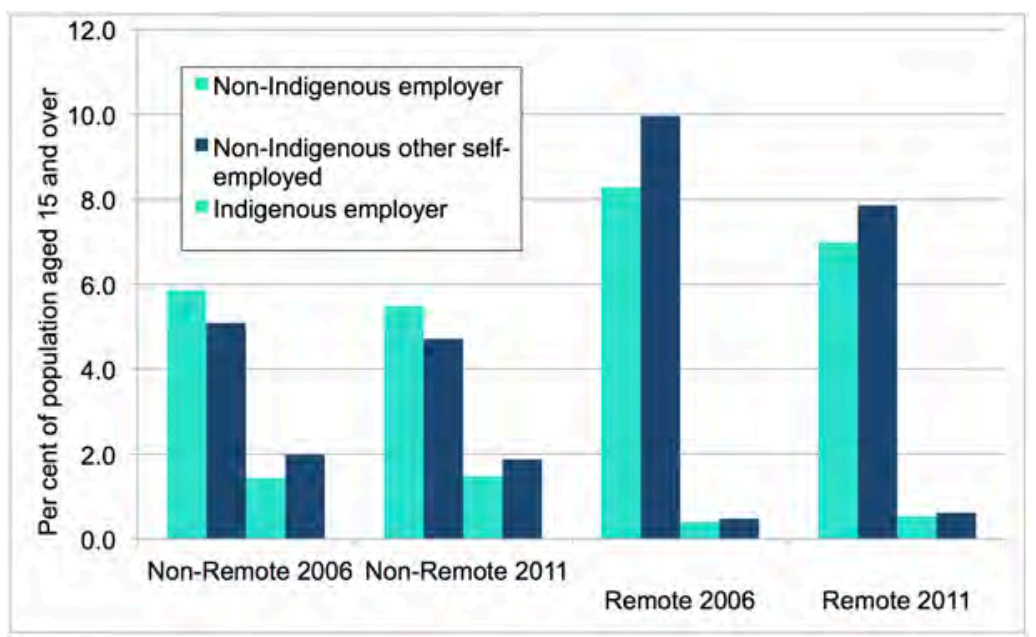

Figure 4: Recent trends in non-Indigenous employer status by remoteness

Note: See note for Figure 3.

Source: ABS Table Builder.

Indigenous self-employment remains exceptionally low in remote areas compared to non-Indigenous rates, but this ratio increased between 2006 and 2011 (from 0.05 to 0.08). Although there was an increase in Indigenous selfemployment between 2006 and 2011, Indigenous residents of remote areas are still around 13 times less likely to be self-employed than other remote residents. Indigenous people in remote areas are drawn from a population less likely to have education, with limited access to credit and banking services (on average), and low levels of social capital; that is, having strong social networks outside the local community (Foley 2006).

\section{Income and estimating the size of the self- employment sectors}

Census data can also provide information on the average personal income that can be combined with the number of self-employed to estimate the monetary value of the size of the self-employment sector in 2006 and 2011. Table 1 reports 
the average personal income in 2011 dollar terms (\$2011) for employers and other self-employed by remoteness category. Before attempting to interpret such data we should note three limitations:

The first limitation is that the income of self-employed is notoriously difficult to measure accurately because of the probable use of non-monetary transfers (including possibility of involvement in the 'grey' or 'cash' economy), and concerns about the incentive of the self-employed to accurately report income (Taylor 1996).

The second limitation is that census data is measured in broad income categories and the self-employed in the top categories may have higher actual income than is conventionally assumed in census based analysis.

A third limitation is that the income of self-employed does not equate with the income of corporate entities - no individual may indicate they are selfemployed with respect to larger businesses.

Another complicating factor is that business income and profits are different from individual income in crucial ways, including the fact that business costs - including allowances to maintain the value and sustainability of the capital investment - need to be deducted. Notwithstanding such qualifications, the changes in incomes of self-employed provide some insights into broad changes in the value of economic activity in the Indigenous self-employment sector.

The incomes for self-employed are relatively static for all categories with the exception of Indigenous employers in remote areas, whose income increased by 20 per cent in real terms. This probably reflects increased use of Indigenous contractors in the mining sector and an increased demand for the services of Indigenous employers. Note that the incomes of other Indigenous self-employed actually fell marginally in real terms. Incomes for non-Indigenous self-employed increased but the extent of the rise was less than that observed for Indigenous employers. 
Agenda, Volume 21, Number 1, 2014

Table 1: Average weekly personal income by self-employment status and remoteness $(\mathbf{2 0 1 1 )}$

\begin{tabular}{lllll}
\hline & $\begin{array}{l}\text { Non-remote } \\
\mathbf{2 0 0 6}\end{array}$ & $\mathbf{2 0 1 1}$ & $\begin{array}{l}\text { Remote } \\
\mathbf{2 0 0 6}\end{array}$ & $\mathbf{2 0 1 1}$ \\
Indigenous & & & & 1,239 \\
\hline $\begin{array}{l}\text { Employer } \\
\text { Other self-employed } \\
\text { Non-Indigenous }\end{array}$ & $\mathbf{1 , 1 2 6}$ & 1,160 & 1,038 & 652 \\
\hline $\begin{array}{l}\text { Employer } \\
\text { Other self-employed }\end{array}$ & $\mathbf{7 9 5 3}$ & $\mathbf{7 2 5}$ & 660 & 1,216 \\
\hline
\end{tabular}

Note: See note for Figure 3. The average income in the top category is one and a half times the lower threshold for the category. The 2006 income is converted to \$2011 using the Consumer Price Index (ABS 2013a).

Source: ABS Table Builder.

In contrast to the situation in non-remote areas, Indigenous employers in remote areas now have a slightly higher income in $2011(\$ 1,239)$ than non-Indigenous employers $(\$ 1,216)$. This may reflect the increased demand for contracting Indigenous services to the mining sector. Given that there was no increase in measured income for other self-employed in remote areas, it may be that selfemployed who do not employ other workers are not the beneficiaries of the apparent expansion in the use of Indigenous contractors in the mining industry. Other possible explanations are that these other self-employed are concentrated in non-mining remote areas or that mining companies prefer to contract larger organisations where other Indigenous people are likely to work (i.e. Indigenous employers or other businesses with Indigenous employment goals, Reconciliation Action Plans etc.). The economic rationale for this second explanation is that mining companies are trying to save on transaction costs while meeting their own published corporate-social-responsibility targets. Accordingly, companies will avoid the cost of having a substantial number of individual contracts with smaller businesses (including businesses involving other self-employed, who are small by definition if measured by the numbers of workers involved).

Table 2 combines this information on income with the estimated number of selfemployed, which is again calculated by multiplying the estimated residential population in an area by self-employment rates reported in Figures 2 and 3. Given that the most substantial change in average income was among remote areas, the estimated size of the self-employment sector is largely driven by the changing number of entrepreneurs. Note that I aggregate employer and other self-employed sectors to make a few basic points. The most obvious point is that even though the size of the Indigenous self-employment is growing over time, it is tiny relative to that attributable to other Australian self-employed. Notwithstanding the fact that Indigenous employers are doing relatively well in 
remote areas, the size of the Indigenous self-employment sector is particularly small in those areas. In view of the rise of affordable flights and the Fifo workforce the location of a business is probably less important than it once was.

Table 2: Aggregate size of self-employment sector in 2006 and 2011 (\$2011m per annum)

\begin{tabular}{lllll}
\hline & Non-remote & \multicolumn{3}{l}{ Remote } \\
\hline & 2006 & 2011 & 2006 & 2011 \\
Indigenous sector & $\$ 389 \mathrm{~m}$ & $\$ 541 \mathrm{~m}$ & $\$ 28 \mathrm{~m}$ & $\$ 50 \mathrm{~m}$ \\
Non-Indigenous sector & $\$ 99,978 \mathrm{~m}$ & $\$ 102,744 \mathrm{~m}$ & $\$ 2,370 \mathrm{~m}$ & $\$ 2,269 \mathrm{~m}$ \\
Total & $\$ 100,367 \mathrm{~m}$ & $\$ 103,285 \mathrm{~m}$ & $\$ 2,398 \mathrm{~m}$ & $\$ 2,319 \mathrm{~m}$ \\
\hline
\end{tabular}

Note: See note for Figure 3.

Source: ABS Table Builder.

Even if one aggregates the size of the self-employment sectors in remote and nonremote areas it is hard to reconcile the incomes of Indigenous self-employed with public claims made about the value of contracts and transactions with Indigenous business. The 2011 census indicates that total Indigenous self-employed income was only \$591 million per annum (i.e. adding the entries for remote and nonremote sectors). This does represent an increase of 42 per cent on the size of the sector in 2006, but is substantially less than the recent commitments to Indigenous contractors by FMG and Rio Tinto. Similarly Rio Tinto aims to allocate contracts to local Indigenous Pilbara businesses that are probably a substantial fraction of the estimated income of Indigenous self-employed in 2011. Even when we abstract from the current location of Indigenous self-employed, it is clear that if contracts of this magnitude were awarded over a short period, the capacity constraints of existing Indigenous businesses would be severely stretched. Ignoring the likely difficulty for Indigenous business in finding sufficient capital to grow their business, it is arguably improbable that the sector can expand rapidly enough to ensure that all inputs are productively employed. Attempting to grow a business quickly can raise a new set of challenges for management that, at the very least, impose a constraint in the level of sustainable and profitable expansion.

Of course one reason for the apparently disproportionate size of these commitments relative to actual income of the self-employed is that they are spread over more than one year. Another explanation is that census estimates of personal income do not include returns to capital (and hence leave out a substantial amount of business transaction value). 


\section{Who are the Indigenous self-employed?}

Hunter (2004) showed that most Indigenous self-employed were involved in small-scale businesses that did not employ any other people. Furthermore, Indigenous self-employed were more likely to be involved in construction and retail sectors, while there was also a disproportionate number in agriculture industries in remote areas. Note that only two per cent of all Indigenous selfemployed in remote areas in 2001 were involved directly in mining.

Indigenous business is generally less segregated from other Australian business than general employment statistics indicate, at least in urban areas (Hunter 2004). Segregation is commonly measured by the dissimilarity index which effectively estimates the proportion of the Indigenous businesses or workers who would have to change industry or occupation for the Indigenous population to have analogous characteristics to that of the non-Indigenous population (Duncan and Duncan 1955). Only 14 per cent of non-remote Indigenous self-employed would have to change industry, which provides some indirect evidence that Indigenous businesses are 'following the money' in those areas. That is, Indigenous businesses in non-remote areas are not disproportionately engaged in industries that are less profitable for the rest of the Australian economy.

Hunter (2004) also argued that occupational distributions of Indigenous and non-Indigenous self-employed were reasonably similar, especially in non-remote areas. Notwithstanding this, Indigenous self-employed were less likely to be managers than non-Indigenous self-employed (especially in remote areas), while they were less likely to be tradespersons in metropolitan areas. One explanation for these observations was the ongoing educational deficits, with Indigenous self-employed being almost half as likely to have Year 12 education as other self-employed. Another feature of Indigenous self-employed was that they tend to be younger than nonIndigenous self-employed, but older than the average Indigenous people.

Table 3 reports the 10 industries with the highest percentage of Indigenous and non-Indigenous self-employed at the time of the latest census in 2011. In these more recent data there are three industries where Indigenous self-employed are disproportionately represented relative to other Australian self-employed: performers; Painting and Decorating; and Gardening Services. The percentage of businesses in each industry is similar for the other seven industries in this table, but those three industries have Indigenous self-employment rates that are a substantial multiple of the relevant non-Indigenous rate. For example, Indigenous self-employed are 2.2 times more likely to work in creative industries than the non-Indigenous self-employed, which may indicate a comparative advantage in such industries (reflecting ongoing demand for Indigenous art and culture at large) and a substantial involvement in cultural and environmental tourism. 
Table 3: Top 10 industries (disaggregated) for Indigenous and NonIndigenous self-employed, 2011

\begin{tabular}{ll}
\hline Indigenous & Non-Indigenous \\
\hline Road Freight Transport & House Construction \\
House Construction & Road Freight Transport \\
Building \& Other Industrial Cleaning Services & Building \& Other Industrial Cleaning Services \\
Carpentry Services & Accounting Services \\
Creative Artists, Musicians, Writers \& Performers & Beef Cattle Farming (Specialised) \\
$\left({ }^{*} 2.2\right)$ & \\
Painting \& Decorating Services ${ }^{*}$ 1.5) & Cafes \& Restaurants \\
Hairdressing \& Beauty Services & Hairdressing \& Beauty Services \\
Gardening Services (*1.4) & Computer System Design \& Related Services \\
Plumbing Services & Carpentry Services \\
Electrical Services & Electrical Services \\
\hline
\end{tabular}

Note: The industries are identified by four-digit Australia and New Zealand Standard Industrial Classification (ABS 2008). These 10 industries represent about one-quarter of business for both groups. Numbers in brackets indicate the extent to which the Indigenous rate exceeds the non-Indigenous rate (in multiples). This table analyses all self-employed because the numbers of employer and other self-employed are too small for the refined level of disaggregation required.

Source: ABS Table Builder.

Given that the industries in Table 3 are based on highly disaggregated classifications, there are relatively few self-employed in each category. Consequently, even though there are six industries in common for both top 10 lists, this is noteworthy and probably indicates that industrial distributions are reasonably similar overall. Apart from the three industries identified above, the only other Indigenous industry not in the non-Indigenous list is plumbing. Of the four industries in the non-Indigenous list that are not in the Indigenous list, three involve a high level of professional skill and education where Indigenous people are historically excluded by virtue of ongoing educational disadvantage and dispossession: accounting, beef cattle farming, and computer system design.

Another noteworthy feature of Table 3 is that mining industries do not feature in the top 10 industries. This observation is not necessarily inconsistent with the large amounts of monies being allocated to Indigenous contractors by FMG and Rio Tinto, as the contractors may just be providing services and inputs that may not be classified as mining per se. Another rationale could be that a small number of Indigenous businesses may hold large and valuable contracts.

The geographic analysis of Hunter (2004) can be extended by greater disaggregation of census information using Indigenous Region-level data (provided in Hunter 2013). Indigenous employers and other self-employed are most likely to reside in the southeast corner of Australia that has the best Indigenous education outcomes relative to other jurisdictions (i.e. the states 
of Victoria, Tasmania and NSW, and the ACT). This is also consistent with the higher population densities in such areas and hence a relatively strong demand of goods and services. With the exception of the ACT where public-sector employment is relatively prominent, non-Indigenous self-employment is also relatively strong in southeast Australia. However, in contrast to the Indigenous self-employed, the highest prevalence of non-Indigenous employers and other self-employed tends to be in remote areas, especially remote NSW. While there are likely to be a number of mining contractors involved in the concentration of self-employed in certain remote areas, the fact that there are substantial number of non-Indigenous self-employed in remote NSW is arguably associated with the concentration of farming and pastoralism in the Murray Darling basin.

Table 4 uses this regional data on self-employment private-sector participation to illustrate the propensity of Indigenous and non-Indigenous employers to hire Indigenous workers. Given that self-employment could be classified as privatesector employment, the measure of private-sector activity excludes all forms of self-employment. Indigenous and non-Indigenous self-employment rates in 37 Indigenous areas are used to predict a local private-sector employment rate using a simple regression model. The coefficient of determination (or $\mathrm{R}^{2}$ statistic) indicates that over 55 per cent of the variation in Indigenous private sector is explained by the distribution of Indigenous employers.

Table 4: Regression of regional Indigenous private-sector employment rates in 2011 (all regressors measured as a percentage of the local population aged between 20 and 64)

\begin{tabular}{lrrr}
\hline & Coefficient & $\begin{array}{c}\text { Standard } \\
\text { errors }\end{array}$ & Significance \\
\hline Indigenous employer & 9.0 & $(4.2)$ & $* *$ \\
Indigenous business without employees & -0.2 & $(4.1)$ & \\
Non-Indigenous employer & -0.5 & $(0.7)$ & $*$ ** \\
CONSTANT & 23.3 & $(4.0)$ & \\
R2 & 0.554 & & \\
\hline
\end{tabular}

Note: Ordinary Least Squares regressions on employment rates for 37 Indigenous Regions. Robust standard errors reported in brackets. ${ }^{*},{ }^{* *}$, and ${ }^{* * *}$ denote coefficient is statistically significant at the $10 \%, 5 \%$, and $1 \%$ level of significance. Regressions for non-Indigenous private sector employment were also estimated but they were not significant at the conventional levels. The private-sector employment rates exclude all self-employed (i.e. excluding employers and self-employed without other workers). In this regression, employers are regarded as 'self-employed'.

Source: Indigenous Region data for 2011 Census from Table Builder.

Indigenous private-sector employment rates are significantly correlated with the local prevalence of Indigenous employers in the working-age population 
(aged between 20 and 64), but not with the prevalence other Indigenous selfemployed. The size of the effect of the employer variable is directly associated with the number of Indigenous workers employed in the private sector. So a one percentage point increase in the prevalence of employers in the Indigenous working-age population is associated with a 9 percentage point increase in the expected local Indigenous private-sector employment rate. In contrast, the prevalence of non-Indigenous employers is not significantly associated with higher rates of Indigenous private-sector employment.

This regression analysis is consistent with Indigenous businesses generating more private-sector jobs for Indigenous workers than other Australian businesses. One recent study of Queensland businesses indicated that Indigenous businesses were over a hundred times more likely to employ Indigenous workers than non-Indigenous businesses (Hunter 2014). One possibility is that Indigenous employers provide a more conducive working environment for Indigenous workers. Another possibility is that such businesses are involved in activities that are more likely to require Indigenous workers, such as cultural tourism or the Indigenous art sector.

Historically there is not much research available on the nexus between businesses and Indigenous workers, but a priori we would expect Indigenous employers to provide working conditions that are sympathetic with the needs and preferences of Indigenous workers (for example, because of greater cultural awareness/ cultural competency). Hunter and Hawke (2001) used linked employeeemployer data from the mid-1990s to find that workplaces with Indigenous employees were more likely than other workplaces to have a written policy on racial harassment and a formal grievance procedure to resolve disputes that arise on either racial or sexual harassment grounds. More recently, Tiplady and Barclay (2007) emphasise how mining companies legitimate their 'social licence to operate' by enhancing employment relationships with Indigenous workers. These findings are worth pursuing in future research as they clearly point to the possibility that demand for goods and services is not the sole reason for establishing an Indigenous business or employing Indigenous workers.

Table 5 presents some census data in relation to incorporated businesses (or proprietary limited companies) and unincorporated businesses (that may include Indigenous organisations and sole traders). By definition, the ABS assumes that owner-managers of incorporated businesses are employees and hence all such businesses have at least one employee. Among incorporated Australian businesses there are many more small businesses employing from one to 19 workers (90 per cent) than larger businesses. For incorporated Indigenous businesses the prevalence of small businesses was even higher (92 per cent). 
Business owners who do not hire any employees are considered to be ownaccount workers and commonly include consultants and tradespeople (ABS 2013b). Amongst the unincorporated Australian businesses with non-Indigenous owner-managers, over two-thirds have no employees. For the unincorporated Indigenous businesses, over three-quarters have no employees. This indicates that sole traders or individual entrepreneurs are particularly important among unincorporated businesses. Unincorporated businesses which employ staff include many law and accounting firms, which are often run as partnerships, some tradespeople and some primary producers (such as farmers).

Table 5: Incorporated and unincorporated businesses, number of employees, 2011

\begin{tabular}{lrr}
\hline & Indigenous & Non-Indigenous \\
\hline Owner-managers of incorporated enterprises & & \\
Nil employees & $0 \%$ & $0 \%$ \\
$1-19$ employees & $92 \%$ & $90 \%$ \\
20 or more employees & $8 \%$ & $10 \%$ \\
Total & $100 \%$ & $100 \%$ \\
COUNTS (in 000s) & 6.1 & 162.5 \\
Owner-managers of unincorporated enterprises & & \\
Nil employees & $77 \%$ & $69 \%$ \\
1-19 employees & $20 \%$ & $26 \%$ \\
20 or more employees & $2 \%$ & $4 \%$ \\
Total & $100 \%$ & $100 \%$ \\
COUNTS (in 000s) & 7.5 & 150.3 \\
\hline
\end{tabular}

Note: An owner-manager of an incorporated enterprise works in his/her own business entity which is registered as a separate legal entity to its members/owners (also known as a 'limited liability company'). An owner-manager of an unincorporated enterprise operates his/her own unincorporated economic enterprise, i.e. a business entity in which the owner and the business are legally inseparable, so that the owner is liable for any business debts that are incurred. It includes those engaged independently in a profession or trade (ABS Census data dictionary). The counts in this table are raw counts and are not adjusted for the census undercount.

Source: ABS Table Builder.

This research has focused on the trends in self-employment because the number of self-employed in the census is historically too low to conduct disaggregated analysis. However, Table 5 illustrates that there is a substantial number of incorporated and unincorporated businesses with Indigenous owner-managers and hence future analysis should track Indigenous business using the more meaningful categories in that table. By taking into account the legal status of the business and the number of employees, these data capture both the legal 
status of the business and the likely industrial relations environment in the various workplaces. While the notion of self-employment has clear limitations, it has allowed us to illustrate the growing importance of Indigenous businesses.

\section{Implications for research and policy}

The remainder of the paper identifies some possible implications of the recent growth in Indigenous self-employment for researchers and policymakers. For example, it is difficult to reconcile the measured size of the Indigenous sector with the public claims made by mining companies and others about the extent of contracting to Indigenous businesses. One explanation is the rather loose or flexible definition of what constitutes an Indigenous business or contract. Setting majority Indigenous equity as the criterion for Indigenous business provides a clear definition, but one still has to establish who is an Indigenous person. Large recent increases in the number of Australians identifying as Indigenous means that it is difficult to take Indigenous identification as given, even in the short run (Biddle 2012). Notwithstanding this, majority ownership should be considered as it would provide clear and meaningful data, albeit with much smaller numbers than are currently evident in census analysis (including this paper).

Supply Nation uses a majority-equity definition of an Indigenous business where a business is 'at least 51 per cent owned by Indigenous Australians and the principal executive officer is an Indigenous Australian and the key decisions in the business are made by Indigenous Australians'. This definition is easy to defend in that one would expect these circumstances to be associated with a considerable measure of Indigenous control. However, the definition is contestable in that it will exclude many firms that may otherwise be classified as Indigenous. For example, a business partnership of an Indigenous and nonIndigenous couple would be excluded by this definition as the Indigenous equity will only be 50 per cent and could well show up in census statistics. It is not surprising that Supply Nation currently certifies only 287 Indigenous businesses, which is a small fraction of the Indigenous entrepreneurs identified in recent census data.

Several important issues arise from the definition of Indigenous businesses that will impact on public claims made on Indigenous contractors. Unlike the situation in the US and Canada, contractors can sign off on the basis of Indigenous participation in providing services even though no Indigenous businesses were involved in the services finally provided (Willmett 2009: 41. Note in some US states it is a felony to fraudulently claim certification as a minority business enterprise). There is no statutory protection of the status of 
minority business in Australia and hence anyone can claim to be an Indigenous contractor even though actual Indigenous involvement is minimal or even nonexistent. Irrespective of whether these misrepresentations are deliberate, or a failure to realise an aspiration to involve Indigenous business, they mislead public debate.

If Indigenous business was consistently defined in terms of majority equity in the company, the value of the sector implied from census data or publicly claimed by mining companies would probably fall dramatically. It is desirable to have a meaningful and robust definition of what constitutes an Indigenous business so that there is some accountability about public claims such as those being made by mining companies, Supply Nation or others.

Ngarda Civil \& Mining is an example of a successful Indigenous business that illustrates some of the difficulties in defining and measuring Indigenous businesses. Ngarda is an Indigenous mining contractor with around 350 employees (of whom over half are Indigenous) and an annual turnover of more than \$150 million. Ngarda claim that they are the largest Indigenous-ownedand-operated contracting company in Australia. According to the company's website (ngarda.dev.madpilot.com.au viewed 13 March 2014), Ngarda is jointly owned by Leighton Contractors (50 per cent), the Ngarda Ngarli Yarndu Foundation ( 25 per cent) and IBA (25 per cent). However, this ownership profile would exclude Ngarda from being classified as being an Indigenous business according to the Supply Nation definition, despite considerable involvement and control by Indigenous people and local communities.

While the majority-ownership definition may affect some large companies such as Ngarda, it is likely to have an even larger effect in reducing the numbers of small Indigenous businesses due to the exclusion of partnerships involving married couples where one partner is non-Indigenous. As Foley (2005) argues, business partnerships involving couples are an important means for Indigenous businesses to overcome the financial, social human-capital constraints facing potential entrepreneurs.

Forrest (2014) argues for an even lower equity threshold, with businesses being eligible for tax-free status and government contracts with as little as 25 per cent equity held by Indigenous stakeholders. The inclusion of board membership in Forrest's proposed definition is concerning as it greatly enhances the scope for strategic behaviour of what are ostensibly non-Indigenous businesses seeking preferential treatment. The idea of creating preference for Indigenous businesses can be a potentially fraught area of policy as it may create an incentive for 'shadow listings' or false claims, as firms chase work under the guise of identified organisations. Some companies may be tempted to install Indigenous people on their boards, in a nominal rather than a substantive capacity, to secure the 
proposed benefits of tax-free status and government contracts. If a substantial number of faux Indigenous businesses were created, this may displace legitimate Indigenous businesses that can demonstrate substantial equity and control from Indigenous stakeholders. On balance, the definition of Indigenous business needs to be clear to minimise rent-seeking and other strategic behaviour.

The self-employment data reported above provide one indicator of Indigenous entrepreneurs that abstracts from the ownership and control issues. However, it is an imperfect proxy as there is no necessary concordance between businesses and people. Ngarda exemplifies this issue in that it is highly unlikely that any one Indigenous person would identify themselves as being self-employed in the census solely for their responsibility in running that business. IBA staff would consider themselves public servants while the members of the Ngarda Ngarli Yarndu Foundation may consider themselves as part of a local Indigenous community organisation. Given that no part of the property or income earned by the Foundation may be paid or otherwise distributed to members, individual economic status is likely to be independent of membership (see www.nnyf.com. $\mathrm{au}$, accessed 26 September 2014). Similarly, other incorporated bodies such as community-controlled businesses and Native Title organisations are unlikely to be included in estimates based on self-employment data from the census. Clearly the definition of an Indigenous business will always be contestable, but policymakers need to clearly identify which economic agents are being targeted and articulate what outcomes the policies are seeking to influence.

Does this research have implications for 'closing-the-gaps' targets in employment? In a mechanical sense, the growing number of Indigenous self-employed makes a tiny contribution to improving Indigenous employment outcomes relative to the rest of the Indigenous labour market (Hunter 1999). Nonetheless, this paper argues that the Indigenous self-employed play a significant role in providing jobs for other Indigenous workers. While the evidence presented in this paper is somewhat indirect, it provides grounds for further research analysing the question: Do Indigenous businesses provide working environments that are conducive to employing and retaining Indigenous workers and otherwise overcoming Indigenous labour market disadvantage? If the answer to this question is in the affirmative, then facilitating Indigenous business may be an effective strategy for substantially reducing the gap between Indigenous and non-Indigenous employment outcomes.

Indigenous business is important in its own right, not only to the extent that it facilitates Indigenous employment in a culturally appropriate workplace. To the extent that having a robust middle class is integral to the achievement of sustainable and independent Indigenous development, it may be time to consider having a separate closing-the-gap target for self-employment. This paper has demonstrated that there is a substantial gap in the entrepreneurial outcomes 
for Indigenous and non-Indigenous Australians. A more appropriate definition of what constitutes an Indigenous business would, in all likelihood, increase the number of Indigenous businesses covered by the targets and supported by relevant policy initiatives. For example, if Supply Nation included partnerships the pool of potential Indigenous sub-contractors would expand considerably and enhance the prospects for linking Indigenous businesses with other companies who need their services. Whatever the definition of Indigenous business adopted, building the capacity of Indigenous business should be a high policy priority.

Some researchers have suggested that 'business' and Indigenous cultural values are sometimes seen to be antithetical, in that the focus on profit and the emphasis on self-interest are at odds with collectivist notions that underpin Indigenous culture (Verbos, Gladstone and Kennedy 2011). The substantial recent growth in Indigenous self-employment is clear evidence against this proposition. Indeed, the story of the 19th-century Indigenous entrepreneurs from Coranderrk, referred to earlier, indicates this hypothesis may have always been a bit dubious in that structural impediments were a more important issue than Indigenous culture in the demise of that enterprise.

\section{References}

Altman, J.C., Biddle, N. and Hunter, B. 2009, 'Prospects for "closing the gap" in socioeconomic outcomes for Indigenous Australians?', Australian Economic History Review 49(3): 225-51.

Australian Bureau of Statistics (ABS) 2008, Australian and New Zealand Standard Industrial Classification (ANZSIC), 2006. cat. no. 1292.0, ABS, Canberra.

2009 Experimental Estimates and Projections, Aboriginal and Torres Strait Islander Australians, 1991 to 2021, cat. No. 3238.0, ABS, Canberra.

_ 2012, Australian Demographic Statistics, cat. no. 3101.0, ABS, Canberra.

_ 2013a, Consumer Price Index, cat. no. 6401.0, ABS, Canberra.

_ 2013b, What's New in Regional Statistics, cat. no. 1386.0, ABS, Canberra.

Biddle, N. 2012, 'Population and Age Structure', CAEPR Indigenous Population Project: 2011 Census Paper 5/2012, CAEPR, ANU, Canberra.

Cantilion, R. 1730, Essai sur la Nature du Commerce en Général, Macmillan for the Royal Economic Society (English translation), London. 
Daly, A.E. 1995, Aboriginal and Torres Strait Islander People in the Australian Labour Market, cat. No.6253.0, ABS, Canberra.

Department of Education, Employment and Workplace Relations (DEEWR) (2011), The New Indigenous Employment Program, DEEWR, Canberra, updated information accessed 26 September 2014 employment.gov.au.

— 2013, The Indigenous Opportunities Policy, DEEWR, Canberra, updated information accessed 26 September 2014 employment.gov.au.

Duncan, O.D. and Duncan, B. 1955, 'A methodological analysis of segregation indexes', American Sociological Review 20(2): 210-17.

Foley, D. 2005, 'Understanding Indigenous Entrepreneurs: A Case Study Analysis', Unpublished Phd Thesis, University of Queensland, Brisbane.

— 2006, 'Indigenous Australian Entrepreneurs: Not Community and Not in the Outback', Discussion Paper No.279 CAEPR, ANU, Canberra.

Foley, D. and Hunter, B. 2013, 'What is an Indigenous Australian Business?', Australian Journal of Indigenous Issues 16(3): 66-74.

Forrest, A. 2014, The Forrest Review: Creating Parity, Commonwealth of Australia, Canberra.

Gray, M., Hunter, B. and Lohoar, S. 2012, 'Increasing Indigenous employment rates', CtG Clearinghouse Issues Paper \# 3, AIHW, Canberra.

Hunter, B.H. 1998, 'Assessing the validity of intercensal comparisons of Indigenous Australians, 1986-96', Journal of the Australian Population Association 15(1): 51-67.

— 1999, 'Indigenous self-employment: miracle cure or risky business', CAEPR Discussion Paper No. 176, CAEPR, ANU, Canberra.

- 2004, Indigenous Australians in the Contemporary Labour Market, ABS cat. No. 2052.0, ABS, Canberra.

- 2013, 'Recent growth in Indigenous self-employed and entrepreneurs', CAEPR Working Paper No. 91, CAEPR, ANU, Canberra.

- 2014, 'Indigenous employment and businesses: Whose business is it to employ Indigenous workers?', Working Paper 95, CAEPR, ANU, Canberra.

Hunter, B.H. and Hawke, A.E. 2001, 'A comparative analysis of the industrial relations experiences of Indigenous and other Australian workers', The Journal of Industrial Relations 43(1): 44-65. 
Lahn, J. 2012, 'Aboriginal Professionals: work, class and culture' in HowardWagner, D., Habibis, D. and Petray, T. (eds), Theorising Indigenous Sociology: developing Australian and international approaches, University of Sydney, Sydney: 1-11.

Pascoe, B. 2008, 'How it Starts' in First Australians, Perkins, R. and Langton, M., Miegunyah Press, Melbourne: 117-72.

Taylor, M.P. 1996, 'Earnings, Independence or Unemployment: Why Become Self-Employed?', Oxford Bulletin of Economics and Statistics 58(2): 253-66.

Tiplady, T. and Barclay, M. 2007, Indigenous employment in the Australian minerals industry, CSRM, Brisbane.

Verbos, A.K., Gladstone, J.S. and Kennedy, D.M. 2011, 'Native American Values and Management Education: Envisioning an Inclusive Virtuous Circle, Journal of Management Education 35: 10-26.

Willmett, N. 2009, 'Why We Cannot Wait: The urgent Need for Strategic Indigenous Business Sector Development and Indigenous Enterprise Integration in Australia', Churchill Fellowship Report 2009, The Winston Churchill Memorial Trust of Australia, Canberra. 
This text taken from Agenda: A Journal of Policy Analysis and Reform Volume 21, Number 1, 2014, published November 2014 by ANU Press, The Australian National University, Canberra, Australia. 